\title{
Performance Assessment of Motorcycle Operation, as a Means of Urban Mobility in Lokoja, Nigeria
}

\author{
Olorunfemi Samuel Oluwaseyi1, Eke Edward², Chukwuemeka Albert Eyinda1, \\ Eno. E. Okoko ${ }^{1}$ \\ ${ }^{1}$ Department of Transport Management Technology, Federal University of Technology, Akure, Nigeria \\ ${ }^{2}$ Department of Urban and Regional Planning, Federal University of Technology, Akure, Nigeria \\ Email: lovesamo001@gmail.com
}

Received 2 August 2014; revised 28 August 2014; accepted 16 September 2014

Copyright (C) 2014 by authors and Scientific Research Publishing Inc.

This work is licensed under the Creative Commons Attribution International License (CC BY).

http://creativecommons.org/licenses/by/4.0/

c) (i) Open Access

\section{Abstract}

Motorcycles contribute significantly to the number of automobiles on the roads in Lokoja, Nigeria. This scenario is attributable to pitiable public transport supply and bad roads that are synonymous to the country Nigeria. Motorcycles are the major means of urban mobility in Lokoja due to the fact that the available taxies within the town operate within a designed route only (Felele-Army Barrack and Ganaja-Felele, vice-versa). The situations have led to high increases in the number of motorcycle operators and patronages in Lokoja. To this fact, the paper assessed motorcycle operation as means of urban mobility in Lokoja. The study was conducted using questionnaires and field observation to collect the required data. Data were also collected from the Federal Road Safety Commission and Commercial Motorcycle Association of Nigeria, Lokoja to compliment the data collected from the commercial motorcycle operators and passengers in the study area. The weekly records of movement were sourced from Okada Riders Association in Lokoja. A total of 1125 commercial operators and 4000 commuters were arrived, while $10 \%$ of the populations were sampled. Altogether 113 commercial motorcycle operators and 400 passengers were sampled respectively and this amounted to 513 samples. Descriptive statistics such as frequency counts and percentages were employed in the data analysis. Findings revealed that unemployment situation in the state have led many people, particularly the youth, into the commercial motorcycle operation in the city and the ability to provide door-to-door service have made many people patronize commercial motorcycle in the area. On this note, Government should create more job opportunities, introduce the use of three wheel cycles and improve on the operational efficiencies of city taxies which will go a long way in reducing road accidents and thus reducing the influx of commercial motorcycles. 


\section{Keywords}

\section{Mobility, Commercial Motorcycle, Passenger, Lokoja}

\section{Introduction}

Mobility refers to the speed of travel and the manner in which travel is undertaken. It is a reflection of people's individual personalities and their status [1]. In the sociological literature, the term "mobility" is usually connected with the idea of "social mobility", referring to an individual's categorical movement up or down the weighbridge of socioeconomic classes. In urban planning term, it connotes spatial movement of people from one location to another, either temporarily or permanently with adequate references to social factor resulting from push or pull factors [2]-[4]. Different modes of transport offer different levels of mobility and accessibility under different circumstance [1] [5]. Through that, people seek to increase their mobility to improve accessibility, through which their desired social and economic activities can be undertaken from a specific point in space [1] [6]. Advances in technological development have led to the production of motorized vehicles for road transportation; this increased motorization has enhanced mobility of people from one point of origin to a particular destination [7].

Meanwhile, the importance of urban transportation within any given setting cannot be overemphasized. This is because transportation is an integral part of all human activities and has great impact on the way, in which societies are organized [8] [9]. Transportation plays a key role in the existence and survival of any urban community because it forms the basis of interaction for work, leisure and residential activity, at the same time, stands as one of the strong forces in the emergence of early settlements [10]. The recognition of the importance of transportation to both developed and developing countries has led to large volume of research work in various modes of urban transportation, in which motorcycle falls among the dominant mode, particularly in the developing nations [8].

Motorcycle, which is a motorized vehicle, emergence as a means of urban mobility, has become a common feature in Asia Countries (e.g. Vietnam, Taiwan, China, etc.) and African Countries [7] [11]-[14], unlike in the developed countries, where motorcycling is undertaken as a form of recreation and leisure, for example, in the United States of America, motorcycles comprise 2\% of registered motor vehicles [14]. The annual production of motorcycles in the world is put at about 45 million with the growth rate in Africa, being between about $12 \%-30 \%$ [15]. For instance, in Nigeria, the government's inability to provide conventional mode of transport has necessitated the use of motorcycles (two-wheeled automobiles) and tricycles (three-wheeled automobiles) to move people, goods and services from one point to another under conditions considered to be unsafe and accident prone [1]. The description of the motorcycle as the most dangerous of all motorized vehicles for transportation can be attributed to its nature and design, e.g. absence of airbags to reduce impact in the event of a collision which propel riders and passengers alike to be vulnerable victims of road traffic crashes [14]. Factors responsible for this can be classified as human and environmental factor. Environmental factors include the condition and nature of the roads, traffic flow, poor visibility at night, while human factors include amongst other things: the attitude and behavior of cyclists on the roads, ignoring safety measures like speed limit, traffic sign, not wearing of crash helmets and protective clothing, alcohol and substance abuse prior to riding, carrying more than the stipulated number of pillion passengers [7] [16].

Lokoja is a confluence and historic city in central Nigeria. It has experienced series of changes of political status in the past five decades: first as provincial capital, later as Local Government headquarters and now as State capital. Consequently, it has attracted population from towns and villages in its region for involvement in different economic activities for survival [9]. However, increases of population in Lokoja coupled with increases in commercial activities have facilitated commercial motorcycle operation in the town due to the fact that motorcycles has the advantage to ply roads that are too narrow or too rough for vehicles and they are also able to manoeuvre in traffic pile-up [17]. The use of Okada (motorcycle) is the dominant mode $(50.0 \%)$ among the available modes of road transportation in Lokoja. This is because motorcycle is the only available means of transport that provides door-to-door service in the area [4]. The increasing use of motorcycles for urban public transport service emerges to fill the gap in the demand and supply of public transport in most urban centres in the country [18]. Meanwhile, [19] opines that the following major factors have attracted the use of motorcycles 
as means of public transport in most places of the world: 1) they complement the concept of multi modal transport chains; 2) serve as cheap transport mode; 3) provide door-to-door transport.

Therefore, this paper seeks to assess motorcycle operations as a means of urban mobility in Lokoja with the emphasis on the following objectives: 1) to assess the magnitude of motorcycle accidents in the study area from 2005 to $2013 ; 2$ ) to examine the increasing pattern of motorcycle operation as a means of urban mobility in Lokoja.

\section{Literature Search}

Two-wheel motorcycles as means of urban passenger transport in Nigeria has a wide range of appellations. These appellations are usually localized in various Nigerian States and Cities. These are: Kabu-Kabu in Sokoto, Achaba in Bauchi, Jos, Yola last flight in Benin City. It is also expressed as "going" in Lokoja, Kafanchan, Akauke or Alalok in Cross Rivers and AkwaIbom States [20].

The global economic recession and the fall-out of the structural adjustment programme between 1987 and 1993 in Nigeria have greatly affected the purchasing power of the government and the populace to replace existing public transport fleets of buses and taxis. By the late 1980s the transportation sector of the economy began to feel the impact of the steady drop in the supply of transport services and the mobility problems started in a different dimension [21]. In the same vein, [22] noted that in spite of the federal and state governments huge investment in public transport services provision, there are still deficiency and in-adequacies of public transport services compared to the surging demand in many urban centres. As a result of these inadequacies of government operated and controlled public transport companies there emerged other modes of public transportation among which are the motorcycle and tricycle.

The two-wheel motorcycles popularly called Okada have become an important means of passenger transportation in most urban and semi-urban centres of Nigeria [23]. An estimated 70 percent of Nigerian cities with over 250,000 inhabitants rely on motorcycles for intra-city public transport services [20]. The increasing use of motorcycles in the developing countries for transportation purposes has been ascribed to socio-economic reasons, convenience in negotiating traffic in congested cities and poorly maintained roads, political reasons and the ease of parking in narrow streets. In Nigeria, transportation with motorcycles has evolved over the years, it gained prominence in the commercial city of Lagos, formerly the federal capital in 1992 due to a deficiency of other means of public transportation, it has been estimated that about 450,000 motorcycles are in the metropolis alone as at 1995 [7] [24], while registration of motorcycles license plates in 2004 and 2005 in the country represented $52 \%$ of all motor vehicle licence plates [18]. It is worthy of note to state that the use of motorcycles for commercial transport not only involves the movement of pillion passengers but also of goods [7].

According to [20], motorcycle (two wheeled machine) was designed to carry two persons, operator inclusive. It started as common mode of intra-city transport in the riverine areas of Delta, Edo, Cross-river, Rivers, and Akwa-Ibom States partly due to the water logged nature of these areas, which latter spread to other cities in other parts of the country where it is now used for intra-city movement of people and goods on commercial basis. The use of motorcycle for public transport is not a new commercial public transport system in Nigeria. It has been the common mode of inter-city transportation in most riverine areas of the country. In the dispersed settlements of eastern states, the use of motorcycle as a mode of transportation cannot be waived-off simply because of its immeasurable role in the inter-rural and rural-urban movement or transport of goods, people as well as commercial services. Invariably, motorcycles have now invaded the suburbs and inner cities, towns and local areas of the country as big commercial transport business [21] [25].

In global perspective, motorbikes are the primary means of motorized transport. According to the Taiwanese government, for example, "the number of automobiles per ten thousand populations is around 2500, and the number of motorbikes is about 5000". In places such as Vietnam, motorbike use is extremely high due to a lack of public transport and low income levels that put automobiles out of reach for many. In Vietnam, motorized traffic consists of mostly motorbikes. The four largest motorbike markets in the world are all in Asia: China, India, Indonesia, and Vietnam. The motorbike is also popular in Brazil's frontier towns. During the global economic downturn of 2008, the motorbike market grew by $6.5 \%$. Recent years have seen an increase in the popularity of motorbikes elsewhere. In the USA, registrations increased by $51 \%$ between 2000 and 2005 . This is mainly attributed to increasing fuel prices and urban congestion [26]. Meanwhile, the major reasons for the emergence of the motorcycles as means of urban mobility in Nigeria and other countries of the world as opined 
by [21] are: 1) Inadequacy and ineffectiveness of the conventional modes of transportation such as the buses and taxis, and ferry and train in very few cities. The overland modes have been unable to provide door to door services, more so that there were no defined bus stops and specific public transport routes; 2) Larger proportions of the urban road net-work are unpaved, while as much as sixty percent of the paved roads are in poor condition [27]. This situation invariably makes it difficult for commercial motorists to link several routes and access to many activities areas. Whereas, motorcycle operators can easily maneuvers the bad roads; 3 ) Adverse economic situation of the country that has wrinkled purchasing power of the working population makes it impossible for many to afford a personal vehicle. In addition, exorbitant cost of new and used imported vehicles and their spare parts make operation of commercial public transport by buses and taxis to be concentrated to areas having paved road network and easily accessible; 4) Preference of the populace for faster means of transport service in the face of poor road condition and persistent traffic congestion; 5) High level of unemployment and underemployment provide the impetus for the secondary and university graduates to earn a living and a steady income. There is no policy on who should operate commercial motorcycle service; as such there is an easy entry for operators of motorcycle. Most motorcycle operators get involve in motorcycle service just to secure a temporary employment; 6) Uncontrolled development at the settlement frontiers of the cities and poor management approaches to curtail limp-frogging of physical development activities. The rate at which new settlements emerge with all types of economic activities far outstrip existing moribund development plans and manpower to monitor physical developments are inadequate. These activities generate trips that require transport services. In absence of conventional public transport services, the motorcycle operators quickly fill the gap and have a field day in determining fares and types of services to render. However, the important operation of motorcycle in savaging urban mobility problems in Nigeria has introduced a new dimension to traffic accidents and safety in the country.

In Nigeria, the contribution of motorcycles has increased the mobility rate of commuters over the years. By coincidence, the level of danger portends by its usage is also quite enormous judging from the wave of losses suffered as a result of accident arising from the conflict between motor vehicles and motor cycles in most urban centres in the country. The share of motor cycle in the total number of trips made in most urban centres in the world is quite substantial particularly for low income households [28]. According to [17] in their study of Trends in Motorcycle Accidents in Lokoja, Nigeria, opined that many studies have been carried out on the use of motorcycles as means of public transportation in Nigeria, among which are [29] identified factors influencing high rate of commercial motorcycle accidents in Nigeria. They found over speeding, wrong overtaking, bad roads, sudden mechanical defects and alcohol intake as major factors. They also discovered that commercial motorcycle riders do not comply with Road Safety Highway Codes. Meanwhile, [30] in his study examined the development and impact of motorcycles as means of commercial transportation in Nigeria. He identified rapid rate of urbanization in the face of inadequate means of transportation, high rate of unemployment prevalent in the country in the 1980 s as a fall-out of the downturn in the Nigerian economy at this period and the relative lucrative nature of commercial motorcycle business as factors responsible for the growth of motorcycle business in Nigeria. Moreover [23] also studied the use of motorcycles as mean of public passenger transport in Yola, Adamawa State. They found that economic depression and inadequate transport facilities were factors giving rise to the use of motorcycles as means of public transportation in Nigeria. Areas in the country which have continued to witness increase in the level of motorcycle operation have also had to contend with its attendant problems in terms of high risk exposure of urban commuters to traffic accidents due to the excesses of motorcycle riders. The situation is worsened by the uncoordinated nature of their operation and the operators' flagrant disregard for traffic rules. Their dangerous operational attitude has increased the unenviable record of road traffic accident fatalities [28].

\section{Study Locale}

Lokoja is both the capital city and a Local Government Area in Kogi State which is located in the North Central Geopolitical Zone of Nigeria. It lies on $7^{\circ} 49^{\prime} \mathrm{N}$ and $6^{\circ} 45^{\prime} \mathrm{E}$ with a population of 195,261 at the 2006 census [31]. Lokoja is one of the oldest cities in Nigeria which enjoyed a great deal of prominence as a trading port city during the boom of European commercial activities in the 1950s and essentially as a confluence city. Lokoja has a heterogeneous population which includes the Yoruba, Igala, Ebira, Oworo and Hausa tribes among others. It is approximately 162 kilometers from Abuja, the Federal Capital Territory of Nigeria and covers an area of about 
3180 square kilometers. Major occupations are farming and fishing. The creation of the state in 1991 and establishment of Obajana Cement Company in the area has also led to the increase in population that has necessitated an increase in motorcycle operation in the area. Figure 1 shows map of Lokoja in its national setting, while Figure 2 shows the map representation of road network of Lokoja.

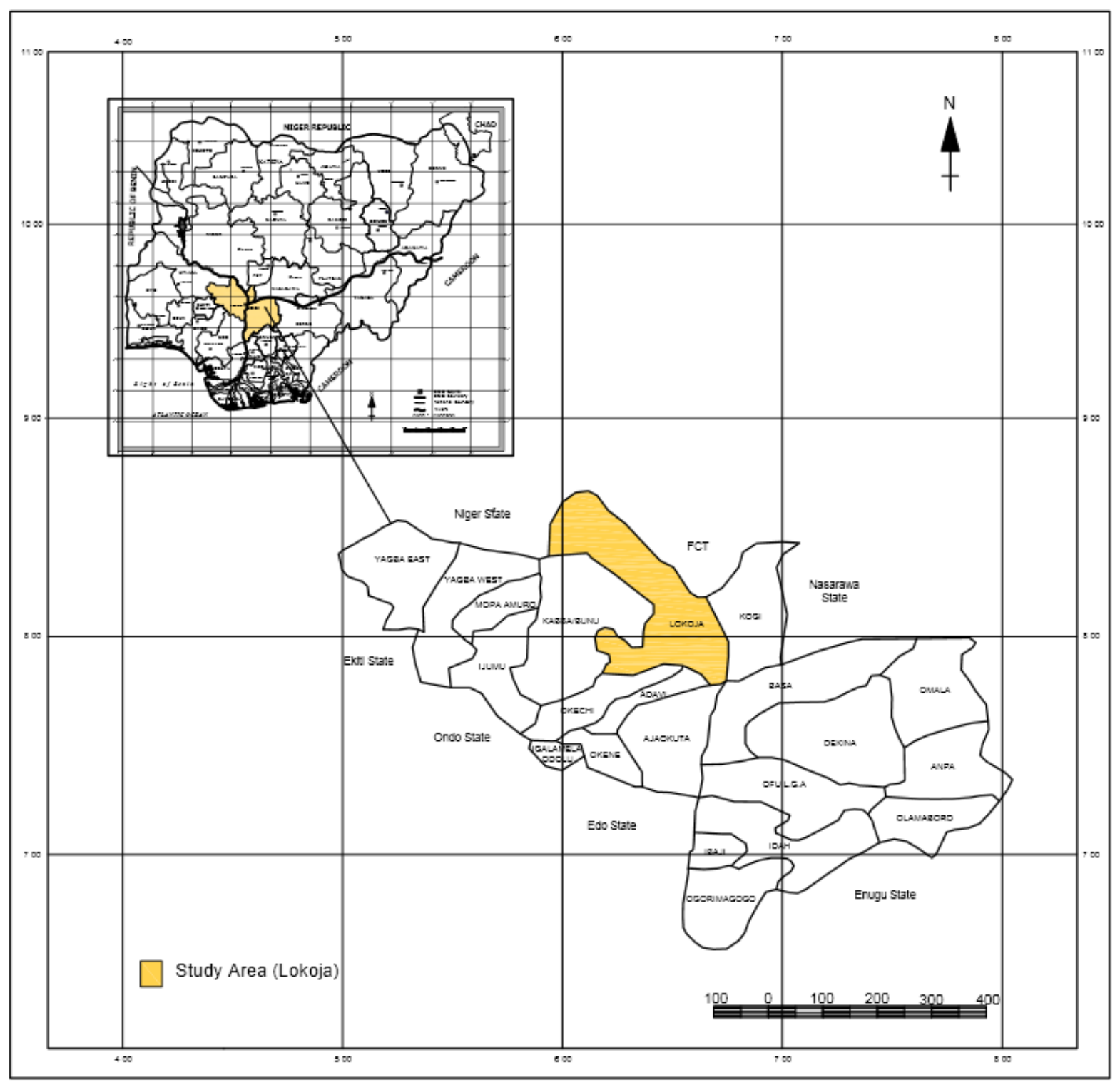

Source: Kogi State Ministry of Land and Housing, Lokoja, 2012.

Figure 1. Map of Lokoja in the National Setting.

\section{Research Methodology}

The study used both primary and secondary data. The primary data relate to information generated through field exercise while the secondary data relate to information gathered from journal and relevant agencies in Lokoja such as State Revenue Office, Federal Road Safety Commission and Okada Riders Association in Lokoja. The population under study is that of the users (motorcycle passenger) and operators of motorcycle in Lokoja. The research instrument used was a well-structured questionnaire in which the variables were structured in question form and responses were sought from the respondents in pre-coded alternatives. Five (5) research assistants were employed and had earlier been tutored by the authors, who administered the questionnaire through face-to- 


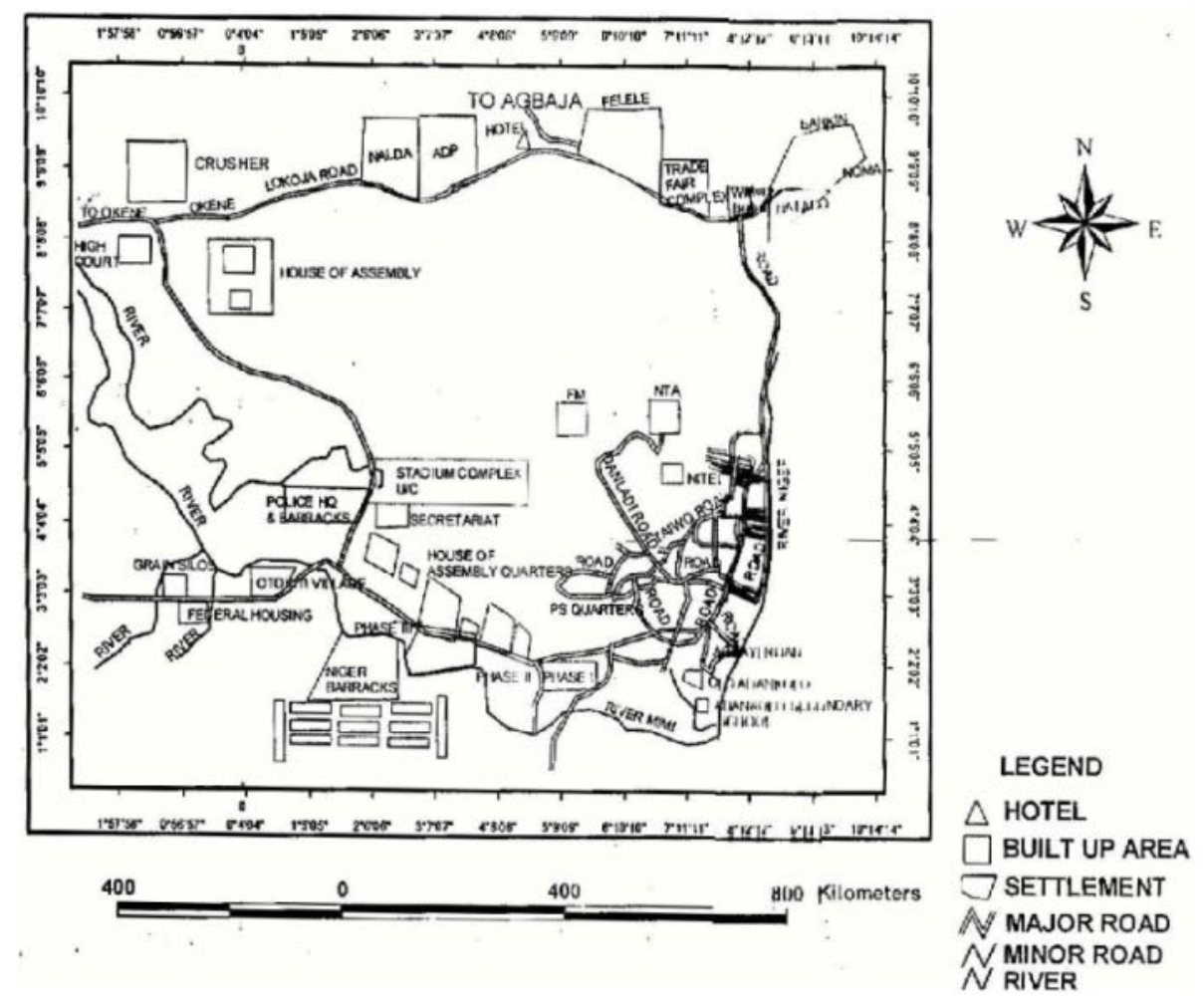

Source: Adapted from [17].

Figure 2. Road Network Map of Lokoja.

face contact with the respondents (Motorcycle Operators and Passengers) at the terminals during working hours for one week in December, 2013. They were instructed to read and interpret the questions to the respondents. In order to determine the sample size for the study, the weekly record of movement were sourced from Okada Riders Association in Lokoja and a total of 1125 commercial operators and 4000 commuters were arrived at while $10 \%$ of the populations were sampled. Altogether 113 commercial motorcycle operators and 400 passengers were sampled respectively and this amounted to 513 samples (Table 1). These were divided across commercial motorcycle terminals in Lokoja.

\begin{tabular}{ccc} 
Table 1. Sample size. & & \\
\hline Target Population & Target Population Number Per Week & $\mathbf{1 0 \%}$ Sample \\
\hline Motorcycle Operators & 1125 & 113 \\
Motorcycle Passengers & 4000 & 400 \\
Total & 5125 & 513 \\
\hline
\end{tabular}

Source: Author's Field Survey, 2013.

The simple random sampling technique was adopted and data collected was subjected to analysis using univariate method, which described the attribute and behavior of each variable.

\section{Findings and Discussion}

\subsection{Socio-Economic Characteristics of Respondents}

As indicated in Appendix 1, it was discovered that $68.8 \%$ of the motorcycle passenger were male and $31.3 \%$ were female. This shows that males are highest patronage of commercial motorcycle in Lokoja then female. This is in agreement with the study of Oni et al. (2011), that males patronize commercial motorcycle riders than their 
femalecounterpart. This may be to the fact, according to [21] that the activities of women in terms of mobility or movement vary differently along gender lines. There are observable gender differentiations in travel behaviour in the space which can be traced to numerous factors that range from age, income level, societal perception, time, distance, family size, etc. The marital status of the motorcycle operators and passengers shows that majority of the operators $(42.5 \%)$ are married and (46.0) of the passengers are single. The occupation status of the respondent reveals that the majority of the motorcycle passengers (43.1\%) are students and $54.1 \%$ of the motorcycle operators claimed to be unemployed and this was one of the major reasons of engaging in motorcycle operation as mean of living. The educational status of the respondents shows majority of the motorcycle operators (40.2\%) and $38.5 \%$ of the passengers are secondary school holders. The age structure of the respondents reveals that majority of commercial motorcycle operators $(29.2 \%)$ and $41 \%$ of the passengers fall between the age of $21-30$ year respectively.

\subsection{Trips Purposes and Choice of Motorcycle of Passengers in Lokoja}

It has been recognized in literature, that trip is usually affected by factors such as age, income, sex, occupation, etc. [32]-[34]. Base on Figure 3 below, it reveals that (35\%) of the passengers embark on daily trips to school, $20.1 \%$ make trips to work places, $27.1 \%$ to market/shop and others which accounted to $19 \%$ make religious and recreational trips daily. This shows that majority of the passenger embark on daily trips to school and this has contributed to the increase number of commercial operators in Lokoja as majority of the operators claimed to make 2000 - $\$ 3000$ daily on a normal working day. This is in agreement with the finding of [20] in Abuja that the highest patronage of commercial motorcycle used it for educational purposes. Meanwhile, the choice of any mode of transport as stated by [33], is highly dependent on the safety, availability of seat, comfort etc. however, the choice of motorcycle varies from one user to another depending on order of preference. In the study it was revealed that about $37 \%$ of the passengers felt the ability to provide door-to-door services made them to patronize commercial motorcycle, $34 \%$ opined that is easily available and accessible, $13.1 \%$ claimed to be cheaper in term of cost of movement, $6 \%$ noted it for comfort and safety and others which accounted to $10.3 \%$ felt the need to beat traffic congestion on the road.

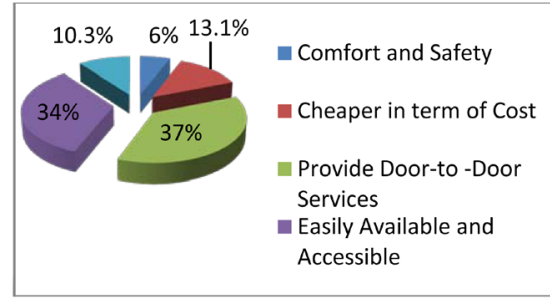

(a)

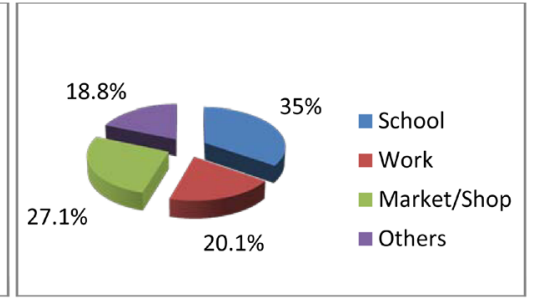

(b)

Source: Author's Field Survey, 2013.

Figure 3. (a) Choice of motorcycle; (b) Trips purposes.

\subsection{Reason for Engaging in Commercial Motorcycle Operation}

According to [1], several reason have been identified to propel people (mostly male) to engage in commercial motorcycle among these are harsh economic environment, unemployment and retrenchment of service, poverty etc. however, in this study, findings shows that $13.3 \%$ of the commercial motorcycle engaged in the operation as a result of retrenchment from service/work, $27.0 \%$ claimed to earn a living, $51.3 \%$ opines to be unemployment and others which accounted for $9 \%$ claimed to raise money for business and academic pursuit. From the study majority of the operators affirmed that unemployment was the reasons that propel them to engage in motorcycle operation in Lokoja. In connection with above, high level of unemployment and underemployment provide the impetus for the secondary and university graduates to earn a living and a steady income [20]. More also [30], opines that high rate of unemployment prevalent in the country has accentuate increases in commercial motorcycle operation in Nigeria. Meanwhile majority of the operators claimed the business is a little bit lucrative as they earn between $\$ 2000.00$ - $\$ 3000.00$ daily and this according to the chairman, Nigeria Motorcycle Transport Union Lokoja, has led to increases in the number of commercial motorcycle operation in Lokoja (see Table 2 and Figure 4). 
Table 2. Number of commercial motorcycle registration in Lokoja from 2005 to 2013.

\begin{tabular}{ccc}
\hline $\mathbf{S} / \mathbf{N}$ & Year of Registration & Number of Commercial Motorcycle Registered \\
\hline $\mathbf{1}$ & 2005 & 302 \\
$\mathbf{2}$ & 2006 & 415 \\
$\mathbf{3}$ & 2007 & 575 \\
$\mathbf{4}$ & 2008 & 803 \\
$\mathbf{5}$ & 2009 & 912 \\
$\mathbf{6}$ & 2010 & 1006 \\
$\mathbf{7}$ & 2011 & 1020 \\
$\mathbf{8}$ & 2012 & 1032 \\
$\mathbf{9}$ & 2013 & 1052 \\
Total & & $\mathbf{7 1 1 5}$ \\
\hline
\end{tabular}

Source: Commercial motorcycle association of Nigeria, Lokoja, 2013.

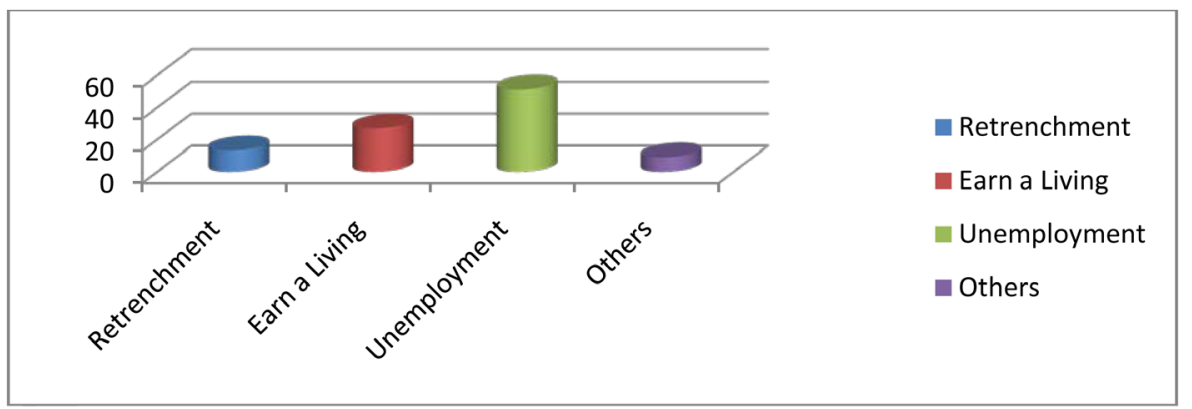

(a)

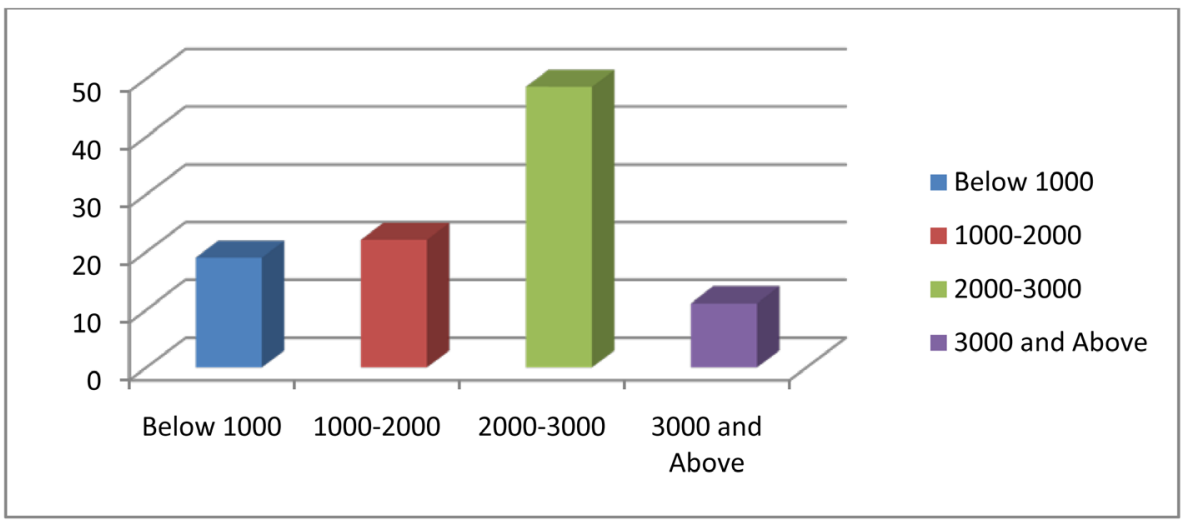

(b)

Source: Author's Field Survey, 2013.

Figure 4. (a) Reason for engaging in commercial motorcycle operation; (b) Daily income of operators.

\subsection{Causes of Motorcycle Accidents}

Motorcycle crashes account for around 1.2 million deaths and 50 million injuries every year [1] [35]. Virtually half of those who died in road traffic accidents globally were pedestrians, cyclists or users of motorcycle which is communally known as vulnerable [1] [36]. However, from the study, findings reveals that majority of the commercial motorcycle operators (29.2\%) and passengers (33.0\%) attributes causes of motorcycle accidents to 
over speeding of the riders. In connection to the above, through an extensive interview with the Sector Commandant of Federal Road Safety Corps Lokoja Commend, he attributes causes of motorcycle crashes to over speeding of the cyclists, over loading, rough overtaking of the riders, dangerous riding, bad road and loss of control by the riders. These factors according to him have contributed to high rate of road accidents in Lokoja and Nigeria at large (see Table 3 and Figure 5).

\begin{tabular}{|cccc}
\hline \multicolumn{4}{|c}{ Table 3. Motorcycle Accidents Trend from the Year 2005-2013. } \\
\hline Year of Accidents & Number of Accidents Occurred & Number Killed & Number Injured \\
\hline $\mathbf{2 0 0 5}$ & 20 & 80 & 100 \\
$\mathbf{2 0 0 6}$ & 76 & 117 & 531 \\
$\mathbf{2 0 0 7}$ & 80 & 186 & 774 \\
$\mathbf{2 0 0 8}$ & 70 & 155 & 553 \\
$\mathbf{2 0 0 9}$ & 71 & 168 & 614 \\
$\mathbf{2 0 1 0}$ & 62 & 386 & 438 \\
$\mathbf{2 0 1 1}$ & 77 & 358 & 618 \\
$\mathbf{2 0 1 2}$ & 87 & 631 & 704 \\
$\mathbf{2 0 1 3}$ & 102 & 815 & 910 \\
Total & $\mathbf{6 4 5}$ & $\mathbf{2 8 9 6}$ & $\mathbf{5 2 4 2}$ \\
\hline
\end{tabular}

Source: Federal road safety commission, Lokoja, 2013.

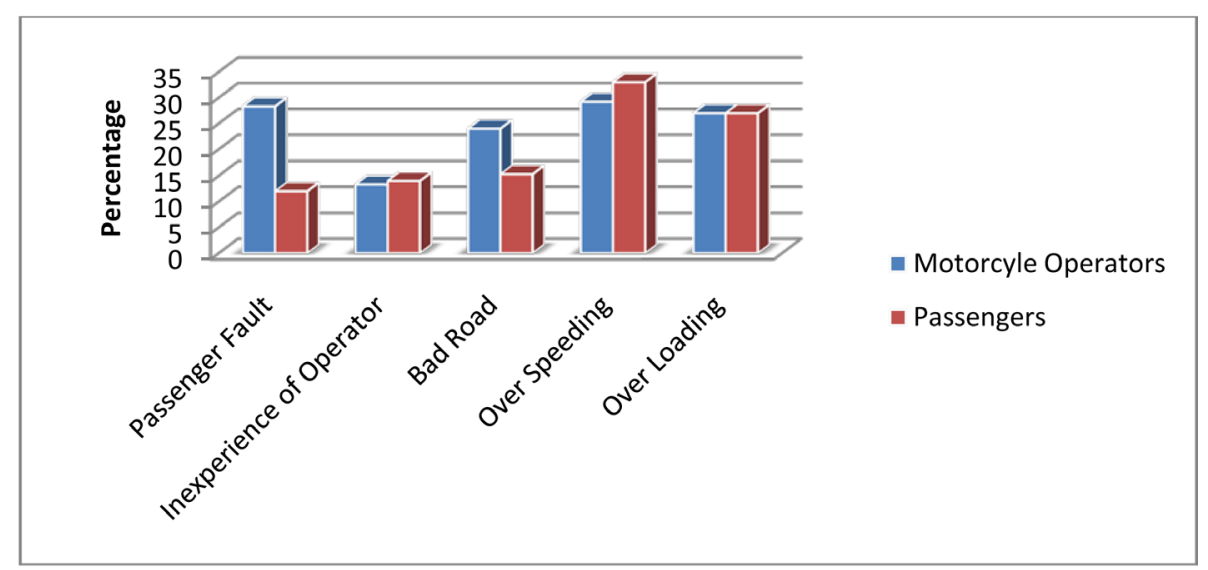

Source: Author's Field Survey, 2013.

Figure 5. Causes of motorcycle accidents.

\subsection{Ways to Reduce Motorcycle Accidents in Lokoja}

From the respondents' opinion on the best way to reduce motorcycle accidents in Lokoja, $14.0 \%$ of the passengers suggested that commercial motorcycle should be banned in the city, $22.0 \%$ of the passengers and $9.7 \%$ of the operators claimed restriction of commercial motorcycle operation to certain routes within the town, followed by sensitization and education of the public (30.0\% of the passengers and $39.8 \%$ of the operators) while $35.0 \%$ of the passengers and $50.4 \%$ of the operators felt that construction of motorcycle lane will reduce motorcycle accidents in Lokoja. In corroboration with the findings above, the sector commandant of Federal Road Safety Corps Lokoja, opines that public awareness and sanitizations of the public (both the users and operators) through media houses (such as television, radio, and newspaper etc., street walk/campaign), road audit that is usually done quarterly by the commission which then forwarded to Federal Road Maintenance Agency (FERMA)for implementation and amendment of the identified sport on the road and enforcement of the uses of safety mate- 
rials such as helmets, hand glove, goggle etc. will go a long way in reducing motorcycle accidents in Lokoja and the Nation at large.

\section{Policy Recommendations and Conclusion}

The study has assessed the operation of commercial motorcycles in Lokoja. From the research finding, employment problems were the major attributes that led majority $(51.0 \%)$ of the commercial motorcycle operators into the work. As a result of that, many of them did not engage in formal training and has results in high rate of commercial motorcycle crashes in the city, which have claimed many lives and rendered some impotent. To worsen this scenario, the sector commandant of Federal Road Safety Lokoja Command opines that non-compliance of most of the cyclists to traffic rules and safety has increase the accidents rate in Lokoja, as majority of them failed to use their safety materials that could have enhanced safe riding and reduced the accidents occurrences. To this end, in order to ameliorate the identified problems associated with the commercial motorcycle operation in Lokoja, the state Government should create more employment opportunity for people, particularly for the youth of the state who are the major work force of the state.

Intensified effort should be made by government to rehabilitate bad roads and even construct motorcycle bike lane particularly in Lokoja where the major means of mobility is motorcycle as majority of the respondents claimed to provide door-to-door services. Introductions of three wheel cycles and improvements of the operational efficiencies of city taxies will go a long way in reducing road accidents and thus reducing the influx of commercial motorcycles. Training and retraining of motorcycle riders must be emphasized and the formation of proper enforcement measures through the Federal Road Safety Corps (FRSC) and Nigeria Police Force (NPF) should be undertaken at all times. In addition, an accurate data base should also be inaugurated and frequently updated to help facilitate effective road monitoring of commercial motorcycle activities for sustainable urban transport planning. This will help in record keeping and trace any accidents victim or crime committed by the operators.

To ascertain level of experience in riding, motorcyclists should be made to undertake tests and licenses issued before they can be permitted to ride on roads. Regulation on compulsory use of safety materials, such as protective head helmets, goggles, hand cloves etc., should be enforced and users (passengers) of commercial motorcycle should be sensitized and educated on the benefit of the usage of protective head helmets.

\section{References}

[1] Oni, S., Fashina, O. and Olagunju, Y.K. (2011) The Motorcycle Crash Characteristics in Lagos State. Nigeria Journal of Environmental Management and Safety, 2, 1-15.

[2] Basorun, J.O. (2004) Basic Element of Urban and Regional Planning. Shalom Publisher, Akure.

[3] Sheller, M. (2011) Mobility. www.sagepub.net/isa/resources/pdf/mobility.pdf

[4] Olorunfemi, S.O. and Basorun, J.O. (2013) Appraisal of Regional Mobility in Lokoja, Nigeria. Journal of Society and Communication, 2013, 420-446.

[5] World Business Sustainable Development (WBCSD) (2001) Monthly 2001 World Mobility at the End of the Twentieth Century and Its Sustainability. Massachusetts Institute of Technology, Cambridge, Massachusetts.

[6] United States Department of Transportation; Bureau of Transportation Statistics (USDOT BTS) (1997) Transportation Statistics Annual Report. Mobility and Access, BTS97S-01, Washington DC.

[7] Akhigbe, O.P. (2010) Motorcycle Related Maxillofacial Injuries in a Semi Urban Town in Nigeria: A Four Year Review of Cases in Irrua Specialist Teaching Hospital. Master's Thesis, Umeå University, Umeå.

[8] Muhammad, S. (2011) An Assessment of the Effectiveness of Tricycle as a Mode of Urban Transportation in Kano Metropolis, Nigeria. Master's Thesis, Ahmadu Bello University, Zaria.

[9] Olorunfemi, S.O. (2013) Assessment of On-Street Parking in Lokoja, Nigeria. Master's Thesis, Federal University of Technology, Akure.

[10] Zakari, T. (2005) Planning for Motorcycle Transport in Katsina State, Nigeria. A Published Undergraduate Project, Ahmadu Bello University, Zaria.

[11] Zhang, J.H., Norton, R., Tang, K.C., Lo, S.K., Zhuo, J.T. and Geng, W.K. (2004) Motorcycle Ownership and Injury in China. Injury Control and Safety Promotion, 11, 159-163. http://dx.doi.org/10.1080/156609704/233/289643

[12] Hung, D.V., Stevenson, M.R. and Ivers, R.Q. (2006) Prevalence of Helmet Use among Motorcycleriders in Vietnam. 
Injury Prevention, 12, 409-413.

[13] Ministry of Transportation and Communications (2007) Monthly Statistics of Transportation and Communications. Ministry of Transportation and Communications, Executive Yuan, Taipei.

[14] National Highway Traffic Safety Administration (NHTSA) (2007) Traffic Safety Facts 2005: Motorcycles. NHTSA, Washington DC.

[15] Oginni, F.O., Ugboko, V.I., Ogundipe, O. and Adegbehingbe, O. (2006) Motorcycle Related Maxillofacial Injuries among Nigerian Intracity Road Users. Journal of Oral and Maxillofacial Surgery, 64, 56-62. http://dx.doi.org/10.1016/j.joms.2005.09.027

[16] Alvi, A., Doherty, T. and Lewen, G. (2003) Facial Fractures and Concomitant Injuries in Trauma Patients. Laryngoscope, 113, 102-106. http://dx.doi.org/10.1097/00005537-200301000-00019

[17] Aderamo, A.J. and Olatunjoye, S. (2013) Trends in Motorcycle Accidents in Lokoja, Nigeria. European International Journal of Science and Technology, 2, 251-261.

[18] Gbadamosi, K.T. (2007) The Emergence of Motorcycle in Urban Transportation in Nigeria and Its Implication on Traffic Safety. International Journal of Transportation Studies, 3, 1-10.

[19] Rietveid, P. (2001) Biking and Walking: The Position of Non-Motorized Transport Modes in Transport System and Traffic Control. Pergamon, UK.

[20] Odumosu, B. and Yaro, D. Perception of Motorcycle Infrastructure, Provision and Use in Abuja Metropolis.

[21] Oyesiku, O.K. and Odufuwa, B.O. (n.d) Gender Perspectives in Travel Behaviour of Motorcycle Passengers in Nigerian Intermediate Cities. Centre for Transport Studies, Olabisi Onabanjo University, Ago-Iwoye.

[22] Oyesiku, O.K. (1996) Regional Analysis of Transport Infrastructure and Socio-Economic Factors of Nigerian Development. Research for Development, 11, 112-128.

[23] Ogunsanya, A.A. and Galtima, M. (1993) Motorcycles in Public Passenger Transport Services in Nigeria: A Case of Yola Town. In: Ikya, O.G., Ed., Urban Passenger Transportation in Nigeria, Heinemann Education Books (Nig) Plc., Ibadan, 195-207.

[24] Ojekunle, A. (1996) Operations and Use of Motorcycles as Mode of Public Passenger Transport. JRSoc Health, 3, 187-190.

[25] Fasakin, J.O. (2001) Some Factors Affecting Daily Profits of Commercial Motorcycles in Akure, Nigeria. Transport Policy, 8, 63-69. http://dx.doi.org/10.1016/S0967-070X(00)00036-6

[26] Nkede, L.N. (2012) The Socio-Cultural Impact of the Introduction of Motobike Taxis in the Rural Community of Tombel, South-West Region Cameroon. Published Master Thesis, University of Yaoundé, Yaoundé.

[27] Torres Martinez, A.J. (2001) Road Maintenance Policies in Sub-Saharan Africa: Unsolved Problems and Acting Strategies. Transport Policy, 8, 257-265. http://dx.doi.org/10.1016/S0967-070X(01)00009-9

[28] Gbadamosi, K.T. (2006) The Emergence of Motorcycle in Urban Transportation in Nigeria and Its Implication on Traffic Safety. Association for European Transport and Contributors, UK.

[29] Ogunmodede, T.A., Adio, G., Ebijuwa, A.S., Oyetola, S.O. and Akinola, J.O. (2012) Factors Influencing High Rate of Commercial Motorcycle Accidents in Nigeria. American International Journal of Contemporary Research, 2, 130-140.

[30] Olubomehin, O.O. (2012) The Development and Impact of Motorcycles as Means of Commercial Transportation in Nigeria. Research on Humanities and Social Sciences, 2, 231-239.

[31] National Population Census (2006) Compressive Result of 2006 Population Census. www.population.gov.ng/index.php/censuses

[32] Okoko, E.E. (2006) Urban Transportation Planning and Modeling. Millennium Publishers, Akure.

[33] Maitri, V. and Sarkar, P.K. (2010) Theory and Applications of Economics in Highway and Transport Planning. Standard Publishers Distributors, Delhi.

[34] Basorun, J.O. and Rotowa, O.O. (2012) Regional Assessment of Public Transport Operations in Nigerian Cities: The Case of Lagos Island. International Journal of Developing Societies, 1, 82-87.

[35] World Health Organization (WHO) (2004) Road Safety Is No Accident: Brochure for World Health Day. World Health Organization, Geneva.

[36] World Health Organization (WHO) (2009) Time for Action. Global Status Report on Road Safety of the World Health Organization, Geneva. 
Appendix 1. Socio-Economic Status of Respondents

\begin{tabular}{|c|c|c|c|c|c|}
\hline \multirow{2}{*}{$\mathbf{S} / \mathbf{N}$} & \multirow{2}{*}{ Socio-Economic of Respondents } & \multicolumn{2}{|c|}{ Operator of Commercial Motorcycle } & \multicolumn{2}{|c|}{ Motorcycle Passengers } \\
\hline & & Frequency & Percentage & Frequency & Percentage \\
\hline \multirow[t]{4}{*}{1} & Sex & & & & \\
\hline & Male & 113 & 100.0 & 275 & 68.8 \\
\hline & Female & - & - & 125 & 31.3 \\
\hline & Total & 113 & 100.0 & 400 & 100.0 \\
\hline \multirow[t]{6}{*}{2} & Marital Status & & & & \\
\hline & Single & 32 & 28.3 & 184 & 46.0 \\
\hline & Married & 48 & 42.5 & 122 & 31.0 \\
\hline & Divorced & 22 & 19.5 & 73 & 18.3 \\
\hline & Widowed & 11 & 10.1 & 21 & 5.3 \\
\hline & Total & 113 & 100 & 400 & 100 \\
\hline \multirow[t]{7}{*}{3} & Occupational Status & & & & \\
\hline & Unemployed & 61 & 54.1 & 58 & 15.0 \\
\hline & Student & 25 & 22.1 & 171 & 43.1 \\
\hline & Trader & 5 & 4.4 & 82 & 21.0 \\
\hline & Artisan/Professional & 20 & 18.1 & 69 & 17.3 \\
\hline & Civil Servant & 2 & 2.1 & 20 & 5.0 \\
\hline & Total & 113 & 100 & 400 & 100 \\
\hline \multirow[t]{6}{*}{4} & Educational Status & & & & \\
\hline & No Formal Education & 15 & 13.3 & 33 & 8.3 \\
\hline & Primary school & 26 & 23.0 & 75 & 18.6 \\
\hline & Secondary School & 45 & 40.2 & 154 & 38.5 \\
\hline & Tertiary Education & 27 & 24.0 & 138 & 34.5 \\
\hline & Total & 113 & 100 & 400 & 100 \\
\hline \multirow[t]{7}{*}{5} & Age Distribution & & & & \\
\hline & $1-10$ Years & - & - & - & - \\
\hline & $11-20$ Years & 15 & 13.3 & 81 & 20.3 \\
\hline & $21-30$ Years & 33 & 29.2 & 162 & 41.0 \\
\hline & 31 - 40 Years & 45 & 40.2 & 112 & 28.0 \\
\hline & 40 Years and Above & 20 & 18.1 & 45 & 11.3 \\
\hline & Total & 113 & 100 & 400 & 100 \\
\hline
\end{tabular}

Source: Author's Field Survey, 2013. 
Scientific Research Publishing (SCIRP) is one of the largest Open Access journal publishers. It is currently publishing more than 200 open access, online, peer-reviewed journals covering a wide range of academic disciplines. SCIRP serves the worldwide academic communities and contributes to the progress and application of science with its publication.

Other selected journals from SCIRP are listed as below. Submit your manuscript to us via either submit@scirp.org or Online Submission Portal.
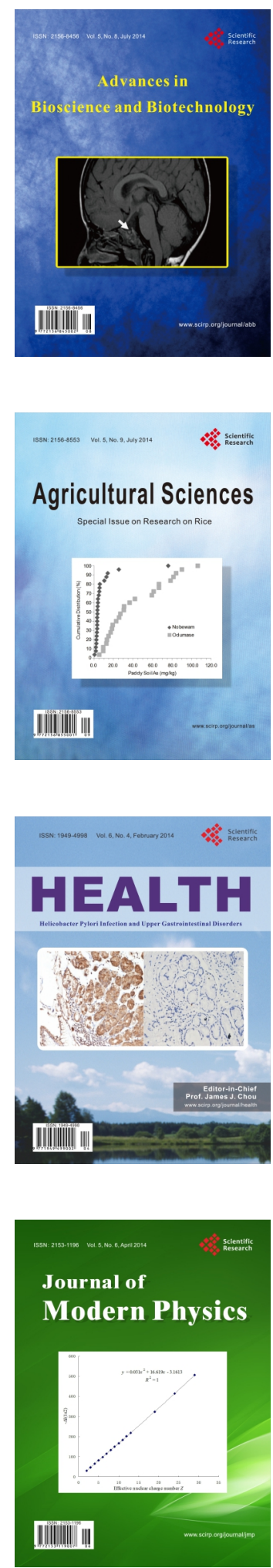
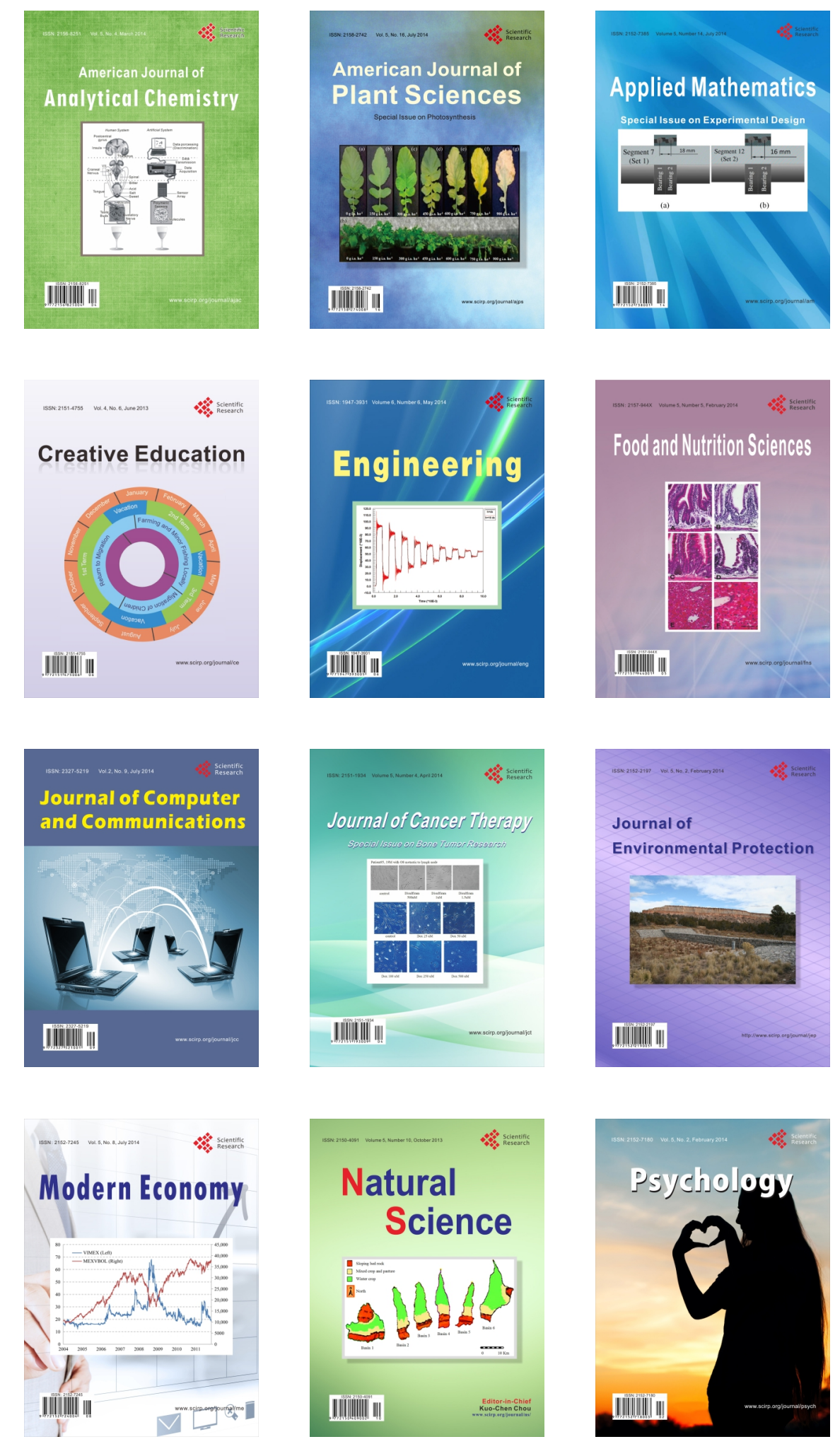